\title{
ÇÖKELEK PEYNİRİ ÜRETİMİNDE ALTERNATİF KAYNAK OLARAK KEFİR KULLANIMI
}

\author{
Tuba Şanlı ${ }^{1 *}$ Elif Ayşe Anlı ${ }^{1}$ \\ ${ }^{1}$ Ankara Üniversitesi Ziraat Fakültesi Süt Teknolojisi Bölümü, Ankara, Türkiye
}

Geliş / Received: 18.12.2019; Kabul / Accepted: 21.01.2020; Online bask1 / Published online: 30.01.2020

Şanlı, T., Anlı, E A. (2020). Çökelek peyniri üretiminde alternatif kaynak olarak kefir kullanımı. GIDA (2020) 45(1) 139-149 doi: 10.15237/gida.GD19162

Sanl, T., Anl, E A. (2020). Use of kefir in çokelek cheese production. GIDA (2020) 45(1) 139-149 doi: 10.15237/gida.GD19162

ÖZ

Çökelek peyniri, yoğurttan üretilen ve daha çok semt pazarlarında satışı yapılan geleneksel bir peynir çeşididir. Çalışmada çökelek peyniri üretiminde kefir kullanımının uygunluğu araştırılmıştır. Yoğurt ve kefirden elde edilen çökelek peynirleri (YÇ, KÇ) fizikokimyasal, mikrobiyolojik ve duyusal nitelikleri yönünden 1., 14. ve 28. günlerde karşılaştırmalı olarak incelenmiştir. Yoğurt ve kefir kullanılarak üretilen çökelek peynirlerinde toplam kurumadde, kül, tuz ve protein değerleri bakımından önemli bir fark belirlenmemiştir. Bununla birlikte kefirden üretilen çökelek peynirinin tat ve koku özellikleri yönünden yoğurttan üretilen çökelek peynirinden farklı olduğu ve panelistler tarafindan daha fazla beğenildiği tespit edilmiştir. Mikrobiyolojik özellik bakımından değerlendirildiğinde, kefirden üretilen çökelek peynirinde toplam aerobik mezofilik bakteri (TAMB) sayılarının (2.71-2.96 log kob/g) yoğurttan üretilen çökelek peynirlerinde belirlenen değerlerden (3.31-3.58 log kob/g) daha düşük olduğu görülmüştür. Sonuçlar, Çökelek üretiminde kefir kullanımının ürünün duyusal özelliklerini ve raf ömrünü olumlu yönde etkilediğini göstermiştir.

Anahtar kelimeler: Kefir, Çökelek peyniri, fizikokimyasal ve mikrobiyolojik özellikler, duyusal değerlendirme.

\section{USE OF KEFIR IN COKELEK CHEESE PRODUCTION}

\begin{abstract}
Çökelek, is a traditional type of cheese produced by using yogurt and mainly sold in local bazaars. In the study, the opportunities of using kefir in Çökelek cheese production were investigated. The Çökelek cheese samples (YÇ, KÇ) obtained from yogurt and kefir were examined comparatively in the $1^{\text {st }}, 14^{\text {th }}$ and $28^{\text {th }}$ days in terms of their physicochemical, microbiological and sensory properties. Distinct difference was not observed in samples' total dry matter, ash, salt and protein content. Moreover, panelists remarked that Çökelek cheese produced from kefir was different from the cheese produced from yogurt in terms of taste and smell characteristics and more liked. Total aerobic mesophilic bacteria (TAMB) counts in Çökelek cheese produced from kefir (2.71-2.96 log kob/g) were lower than cheese produced from yogurt (3.31-3.58 log kob/g). Results indicated that use of kefir in Çökelek cheese production was favorable for sensory and also shelf life characteristics.
\end{abstract}

Keywords: Kefir, Çökelek cheese, physicochemical and microbiological properties, sensory evaluation.

\footnotetext{
*Yazışmalardan sorumlu yazar / Corresponding author

(t): tcetin@agri.ankara.edu.tr (ग) (+90) 3125961527

冝: (+90) 3123182219

Tuba Şanlı; ORCID no: 0000-0001-6747-2617

Elif Ayşe Anlı; ORCID no: 0000-0002-0524-4851
} 


\section{GİRİ̧̧}

Çökelek peyniri, ülkemizde özellikle kırsal bölgelerde Beyaz peynir ve Tulum peynirinden sonra en çok tüketilen peynir çeşitlerinden birisidir. Geleneksel olarak yayık tereyağ 1 üretiminde, yoğurdun sulandırılarak yayıklanması işlemi sonrasında kalan yayıkaltına 1sıl işlem uygulanarak üretilmektedir (Karabulut vd., 2007; Şanlıdere Aloğlu vd., 2012). Çökelek peyniri ucuz olmasının yanı sira, kazein ve serum proteinlerini bir arada içermesi ve az yağlı ya da yağsız olması ile sağlıklı beslenmede tercih edilmesi gereken bir peynir çeşididir (Kavaz vd., 2012; Celem vd., 2018; Ergene ve Arslan 2019).

Kefir orijini Kafkasya olan ve geleneksel olarak sütün kefir danesi ile fermantasyonu sonucu üretilen bir süt ürünüdür (Kakisu vd., 2011; Ürkek vd., 2011; Dertli ve Çon, 2017; Yıldız-Akgül vd., 2018). Endüstriyel düzeyde ise; kefir ve kefir danelerinden izole edilmiş saf mikroorganizmalardan oluşan hazır ticari starter kültür ile üretim sağlanır. Diğer süt ürünlerinden farklı olarak kefir, tek bir türe ait mikrofloranın metabolik aktivitesi sonucu değil karışı bir mikrofloranın fermantasyonu sonucu açığa çıkan bir üründür. Kefir mikroflorası başlica laktobasiller olmak üzere, streptokoklar, laktokoklar, asetik asit bakterileri ve mayalardan oluşmaktadır (Simova vd., 2002; Güzel Seydim vd., 2011; Nielsen vd., 2014). Çok sayıda mikroorganizmayı içeren kefirin, sahip olduğu mikrofloranın fermantasyon sürecinde ürettikleri metabolitlere bağlı olarak antibakteriyel, antihipertansif, bağışıklık sistemini destekleyici, bağırsak florasını dengeleyici özellikleri ile sağlık üzerine olumlu birçok etkisinin bulunduğu bilinmektedir (Ürkek vd., 2011; Esmek ve Güzeler, 2015; Bengoa vd., 2018; Weschenfelder vd., 2018). Konuyla ilişkili olarak da literatürde kefir ile ilgili yapılan çalışmaların yanı sıra, kefir starter kültürü kullanılarak üretilen, özellikle bazı peynir çeşitleri ile yapılan çalışmalar dikkat çekmektedir (Dimitrellou vd., 2015; Ribeiro Melo vd., 2018; Weschenfelder vd., 2018). Bu çalışmada, yirmi birinci yüzyılın yoğurdu olarak bilinen kefirin besleyici özelliği ile tanınan, geleneksel olarak üretilen ve lokal olarak tüketilen bir peynir çeşidi olan çökelek üretiminde kullanılabilirliği araştırılmıştır. Yoğurt ve kefir kaynaklı olarak üretilen çökelek peynirlerinin kimyasal, mikrobiyolojik ve duyusal özellikleri incelenmiştir.

\section{MATERYAL VE YÖNTEM \\ Materyal}

Araştırmada hammadde olarak kullanılan çiğ inek sütü Ankara Üniversitesi Ziraat Fakültesi Hayvancllık İşletmesi'nden temin edilmiştir. Çökelek peyniri üretiminde kullanılan yoğurt ve kefir için starter kültür olarak sırasıyla YO-MIX R06 LYO (500 DCU, Danisco, Germany) ve CHOOZIT $^{\circledR}$ Kefir DC (LYO 1000 1, Danisco, Germany) kullanılmıştır. Liyofilize kültürlere kullanmadan önce \% 12 (w/w) kurumaddeli rekonstitüe sütte ön aktifleştirme işlemi uygulanmıştır.

\section{Yöntem}

Deneme örneklerinin üretimi Ankara Üniversitesi Ziraat Fakültesi Süt Teknolojisi Eğitim Araştırma ve Uygulama işletmesinde mevcut donanımlar kullanılarak gerçekleştirilmiştir. Çiğ süte $85^{\circ} \mathrm{C}$ 'de 15 dakika 1sıl işlem uygulanmış ve daha sonra kefir ve yoğurt üretimi için iki kısma ayrılmıştır. Kefir üretiminde kullanılacak ilk kısım süt, $22^{\circ} \mathrm{C}^{\prime}$ ye soğutulduktan sonra \% 5 kefir starter kültürü ilave edilerek $22^{\circ} \mathrm{C}^{\prime}$ de $\mathrm{pH}$ 4.5-4.6'ya ulaşıncaya kadar (yaklaşık 18 saat) inkübasyona bırakılmıştır. Yoğurt üretiminde kullanılan ikinci kısım süte ise, $45^{\circ} \mathrm{C}^{\prime}$ ye soğutulduktan sonra \% 2 yoğurt starter kültürü ilave edilerek $43-44^{\circ} \mathrm{C}^{\prime} \mathrm{de} \mathrm{pH}$ 4.6' ya ulaşıncaya kadar inkübasyon işlemi uygulanmışstır. Çökelek peyniri üretim yöntemi Şekil 1'de verilmiştir. Çökelek peynir örnekleri, $4^{\circ} \mathrm{C}$ 'de depolanarak 1., 14. ve 28. günlerde fizikokimyasal, mikrobiyolojik ve duyusal özellikleri yönünden incelenmiştir.

\section{Kimyasal analizler}

Peynir örneklerinde toplam kurumadde ve kül içerikleri gravimetrik yöntemle, yağ içeriği Gerber metodu ile, tuz içeriği ise Mohr titrasyon yöntemiyle belirlenmiştir (Hooi vd., 2004). Peynir örneklerinin titrasyon asitliği Hooi vd. (2004) tarafından bildirilen yönteme göre belirlenmiş ve sonuçlar \% laktik asit cinsinden ifade edilmiştir. Örneklerin $\mathrm{pH}$ değeri dijital pH-metre (MP 225, 
Mettler-Toledo GmbH, Giessen, Germany) kullanılarak saptanmıştır. Toplam azot (TN) içerikleri Kjeldahl yöntemine göre tayin edilmiştir (IDF, 1993). Bulunan değer 6.38 ile çarpılarak \% toplam protein miktarı belirlenmiştir. Örneklerin $\%$ nem içerikleri OHAUS marka nem tayin cihazı (MB 45; Parsippany, NJ, USA) ile tespit edilmiştir.

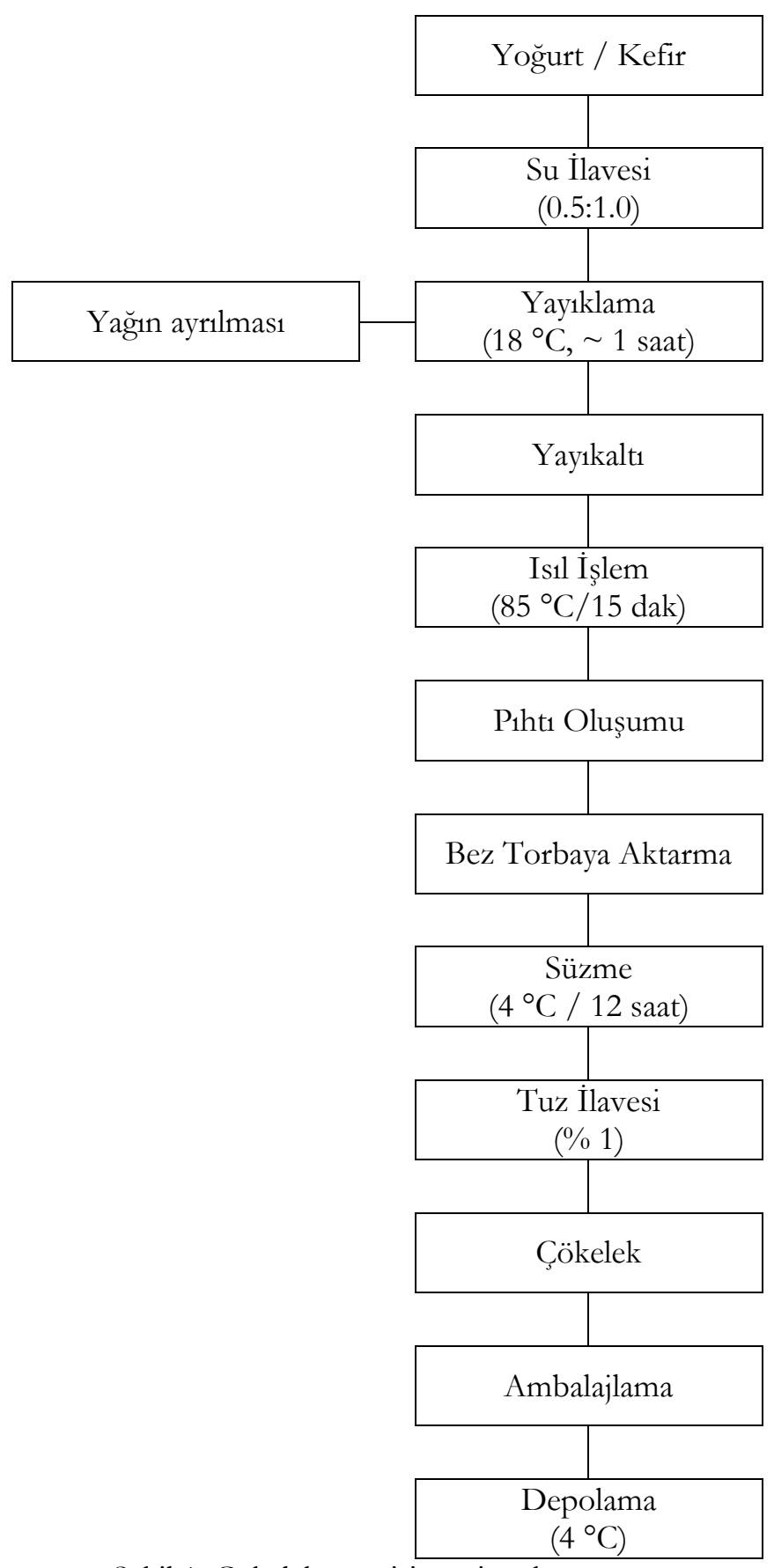

Şekil 1. Çökelek peyniri üretim akış şemas1

Figure 1. Flow chart Cökelek, cheese production 


\section{Renk analizi}

Çökelek peyniri örneklerinin renk özelliklerini ifade eden $L^{*}, a^{*}$ ve $b^{*}$ değerleri, depolamanın 1 ., 14. ve 28. günlerinde kromametre cihazı (Konica Minolta CR 410, Sensing Inc., Osaka, Japan) kullanılarak ölçülmüsstür. Örnekler arası renk farklılı̆̆ını ortaya koymak üzere örneklerde depolama günlerinde aşağıdaki eşitlikten yararlanılarak $\Delta E$ değeri hesaplanmıştır (Chudy vd., 2019). Eşitlikte verilen $\Delta L, \Delta a$ ve $\Delta b$ değerleri söz konusu günlerde deneme örnekleri için ölçülen $L^{*}, a^{*}$ ve $b^{*}$ değerleri dikkate alınarak ve yoğurt çökeleği kontrol örneği olarak kabul edilerek hesaplanmıştır.

$$
\Delta E=\left(\Delta L^{2}+\Delta a^{2}+\Delta b^{2}\right)^{\frac{1}{2}}
$$

\section{Mikrobiyolojik analizler}

Örneklerin mikrobiyolojik analizinde 10'ar gram çökelek peyniri örneği $90 \mathrm{~mL}$ steril ringer (1/4 strength, Merck, Darmstadt, Germany) çözeltisinde magnetik karıştırıcı (Heidolph MR Hei-Tec, Schwabach, Germany) ile homojen hale getirilmiştir. Hazırlanan seri dilüsyonlardan dökme plak yöntemi ile ekim yapılmıştır. Toplam mezofilik aerobik bakteri (TAMB) sayımında Plate Count Agar (PCA, Merck) besiyeri kullanılmıștır. Ekimi yapılan örnekler $37^{\circ} \mathrm{C}$ 'de 48 saat süreyle inkübasyona bırakılmıştır. Sayım sonuçları koloni oluşturan birim sayısının logaritması alınarak (log kob/g) verilmiştir (Halkman, 2005).

\section{Duyusal değerlendirme}

Peynir örneklerinin duyusal değerlendirmesi Ankara Üniversitesi Ziraat Fakültesi Süt Teknolojisi Bölümü öğretim elemanlarından oluşan, süt ve süt ürünlerinin duyusal değerlendirmesi konusunda deneyimli 8 panelist tarafindan gerçekleştirilmiştir. Örneklerin duyusal özellikleri depolamanın 1., 14. ve 28. günlerinde yapılmıştır. İki aşamalı olarak yapılan duyusal değerlendirmede ilk olarak koku, lezzet, görünüş ve yap1 özellikleri yönünden sunulan 2 örnek arasında fark olup olmadığ1 değerlendirilmiş, ikinci aşamada ise puanlama testi ile yine aynı özellikler yönünden farklilığın derecesi belirlenmeye çalışılmıştır (Altuğ- Onoğur ve
Elmac1, 2015). Duyusal değerlendirme için örnekler 3 haneli sayılar ile rastgele kodlanmıs, plastik kapaklı kaplar içerisine yerleştirilmiş ve ağız tadını iyileştirmek üzere 1 bardak su eşliğinde panelistlere sunulmuştur.

\section{İstatistiksel analiz}

Araştırma sonucu elde edilen verilerin istatistiksel olarak değerlendirilmesinde SPSS (SPSS Version 20.0, IBM Corp. Armonk, NY, USA, 2011) programı kullanılmıştır. Örnekler arası farklılığın belirlenmesinde bağımsız gruplar arası t-testi uygulanmıștır. İki tekerrürlü olarak gerçekleștirileren çalışmada elde edilen veriler ortalama \pm standart hata olarak verilmiștir. Verilerin depolama günlerindeki karşılaştırılmasında ise tek yönlü varyans analizi (ANOVA) uygulanmış ve istatistiksel olarak önemli olan farklliklar ( $P$ $<0.05)$ Tukey testi ile belirlenmiştir.

\section{TARTIŞMA VE SONUÇ}

\section{Kimyasal özellikler}

Çökelek peyniri örneklerinin üretiminde kullanılan yoğurt ve kefir yayıkaltlarına ilişkin genel bileşim özellikleri ortalama olarak \% 2.5 protein, $\% 0.1$ yağ ve $\% 6$ kurumadde olarak tespit edilmiştir.

Çökelek peyniri örneklerinin kimyasal özellikleri Çizelge 1'de verilmiştir. Yoğurt ve kefir kullanılarak üretilen çökelek peynirlerinin toplam kurumadde, kül, tuz ve protein değerleri arasındaki farklıllğın istatistiksel açıdan önemli olmadığı bulunmuştur $(P>0.05)$. Her örnek kendi içerisinde değerlendirildiğinde, depolama sürecinde de söz konusu kimyasal özelliklerde belirlenen değişimlerin istatistiksel açıdan önemli olmadığ1 $(P>0.05)$ görülmüştür.

Çökelek peynirlerinin toplam kurumadde $(\% 21.47$ - 24.54) ve yă içerikleri $(\% 1.5$ - 2) bakımından Celem vd. (2018) tarafindan 20 çökelek peynirinde belirlenen toplam kurumadde (ortalama \%23.9 \pm 2.4 ) ve yağ içerikleri (ortalama $\% 1.6 \pm 0.8)$ ile benzerlik gösterdiği tespit edilmiștir. Bununla birlikte, Çardak (2012) ve Kavaz vd. (2012) tarafından yapılan çalıșmalarda çökelek peynirlerinin toplam kurumadde ve yağ içeriklerinin daha yüksek olduğu belirlenmiştir. 
Nem değerleri \%70-82 aralı̆̆ında olan yağsız peynirler yumuşak ve taze peynir olarak sinıflandırlmaktadır (Fox, 1993). Bu sınıflandırmaya göre deneme örnekleri çökelek peynirlerinin $\% 71.35$ - 73.36 aralı̆̆ında değişen nem değerleri ile taze peynir grubunda yer aldığ1 tespit edilmiştir. Çökelek peyniri olgunlaştırma olmadığ1 sürece taze olarak tüketilen bir peynir çeşidi olarak bilinmektedir.

Çizelge 1. Çökelek peynirlerinin kimyasal özellikleri

Table 1. Chemical properties of Cökelek cheeses

\begin{tabular}{lccc}
\hline $\begin{array}{l}\text { Özellikler } \\
\text { Properties }\end{array}$ & $\begin{array}{c}\text { Depolama (Gün) } \\
\text { Storage (Day) }\end{array}$ & YÇ & KC \\
\hline Kurumadde (\%) & 1 & $22.86 \pm 2.19$ & $24.54 \pm 1.17$ \\
Dry matter (\%) & 14 & $22.98 \pm 1.62$ & $24.22 \pm 0.75$ \\
\hline \multirow{2}{*}{ Nem (\%) } & 28 & $21.47 \pm 1.07$ & $23.97 \pm 1.12$ \\
Moisture (\%) & 1 & $73.36 \pm 0.01$ & $71.35 \pm 0.01$ \\
& 14 & $73.26 \pm 1.05$ & $71.76 \pm 0.16$ \\
Titrasyon asitliği (\% LA) & 28 & $73.35 \pm 0.66$ & $71.72 \pm 0.09$ \\
Titratable acidity (\% LA) & 1 & $1.59 \pm 0.04$ & $1.68 \pm 0.02$ \\
& 14 & $1.66 \pm 0.02$ & $1.72 \pm 0.04$ \\
pH & 28 & $1.70 \pm 0.08$ & $1.72 \pm 0.09$ \\
\hline \multirow{2}{*}{ Kül (\%) } & 1 & $4.35 \pm 0.04$ & $4.42 \pm 0.01$ \\
Ash (\%) & 14 & $4.27 \pm 0.07$ & $4.38 \pm 0.01$ \\
& 28 & $4.29 \pm 0.06$ & $4.40 \pm 0.01$ \\
\hline \multirow{2}{*}{ Protein (\%) } & 1 & $1.44 \pm 0.21$ & $1.47 \pm 0.06$ \\
Protein (\%) & 14 & $1.41 \pm 0.49$ & $1.51 \pm 0.53$ \\
\hline \multirow{2}{*}{ Tuz (\%) } & 28 & $1.55 \pm 0.01$ & $1.59 \pm 0.09$ \\
Salt (\%) & 1 & $19.71 \pm 2.14$ & $20.79 \pm 0.62$ \\
& 14 & $19.55 \pm 1.25$ & $20.15 \pm 1.53$ \\
\hline YC Yogitt & 28 & $21.21 \pm 0.02$ & $20.34 \pm 0.03$ \\
\hline
\end{tabular}

YÇ: Yoğurt kullanılarak üretilen Çökelek peyniri (kontrol), KÇ: Kefir kullanılarak üretilen Çökelek peyniri

YC: Cö̈kelek cheese produced from yogurt (control), KC: Çökelek, cheese produced from kefir.

Çökelek peynirlerinin kül değerlerinin \%1.411.59 aralığında değiştiği belirlenmiştir (Çizelge 1). Elde edilen sonuçların Şanlıdere Aloğlu vd. (2012) tarafindan Karadeniz bölgesine has bir çökelek peyniri olan Minci peynirlerinde tespit edilen ortalama kül değerleri (\%1.68) ile benzerlik gösterdiği, ancak; Karabulut vd. (2007) ve Kavaz vd. (2012) tarafindan bulunan değerlerden (sırasiyla $\% 4.1$ ve $\% 4.78$ ) düşük olduğu belirlenmiştir. Örneklerin kül değerlerindeki farklılıkların kullanılan hammaddenin bileşim özellikleri ve çökelek peynirlerinin tuz içeriklerine bağlı olduğu düşünülmüştür.

Protein düzeyleri bakımından yoğurt ve kefirden üretilen çökeleklerdeki değişimin \%19.55-21.22 arasında olduğu Çizelge 1'den görülmektedir. Bu değerlerin Minci peynir örneklerinde belirlenen ortalama değerlerden (\%9.56) daha yüksek olduğu (Şanlıdere Aloğlu vd., 2012), ve Karabulut vd. (2007) tarafından yapılan başka bir çalışmada elde edilen değerler ile $(\% 20)$ benzerlik gösterdiği tespit edilmiştir. Çökelek peyniri örneklerinin 
protein içerikleri bakımından istatistiki olarak önemli bir farkın olmaması $(P>0.05)$ üretimde aynı hammaddenin kullanımından ileri gelmektedir. Çökelek peyniri konusunda yapılan çalışmalar ile mevcut çalışma örneklerinin bileşim özellikleri yönünden farklı sonuçların elde edilmesinin kullanılan hammadde ve üretim yöntemine bağlı olduğu söylenebilir.

Çökelek peyniri örneklerinin asitlik düzeyini gösteren $\mathrm{pH}$ ve titrasyon asitliği değerleri Çizelge 1 'de verilmiştir. Örneklerin $\mathrm{pH}$ değerlerinin 4.27 4.42 ve titrasyon asitliği değerlerinin ise laktik asit cinsinden \%1.59 - 1.72 aralığında değiştiği belirlenmiştir. Kefirden elde edilen çökelek peynirinde asitlik düzeyinin, yoğurttan üretilen çökelek peynirinden daha yüksek olduğu tespit edilmiştir. Ancak, çökelek peynirlerinin asitlik değerleri arasındaki farklılı̆̆ın istatistiksel açıdan önemli olmadığ $(P \quad>0.05)$ tespit edilmiştir. Depolama sürecinde örneklerin asitlik düzeylerinde artış olduğu belirlenmiş, ancak; $\mathrm{pH}$ ve titrasyon asitliği düzeylerinde görülen bu değişimin istatistiksel açıdan önemli olmadığı bulunmuştur $(P>0.05)$. Depolama sürecinde örneklerin asitlik düzeyindeki artı̧ laktozdan laktik asitin oluşumu ile açıklanmaktadır (Temiz vd., 2009; Irkın, 2011). Peynirlerde asitlik düzeyi hammadde bileşimi, kullanılan starter kültür, üretim yöntemi, depolama koşulları gibi pek çok faktöre bağlı olarak değişebilmektedir (Fox vd., 1993). Çardak (2012) çalışmasında ç̧ökelek peynirlerinde $\mathrm{pH}$ ve titrasyon asitliği değerlerini sirasiyla, 2.96-5.35 ve \%0.25-0.79 (\% Laktik asit) aralığında değişim gösterdiğini ve Karabulut vd. (2007) ise örneklerde $\mathrm{pH}$ değerini 3.95 ve titrasyon asitliğini laktik asit cinsinden \%0.97 olarak tespit etmişlerdir. Şanlıdere Aloğlu vd. (2012), Minci peynirlerinde $\mathrm{pH}$ değerinin 4.257.25 aralığında olduğunu ve titrasyon asitliğinin ise laktik asit cinsinden \%0.30-1.24 olduğunu tespit etmişlerdir.

\section{Renk özellikleri}

Çökelek peyniri örneklerinin depolamanın 1., 14. ve 28. günlerinde ölçülen $L^{*}, a^{*}$ ve $b^{*}$ değerleri Çizelge 2'de verilmiştir. Gıdalarda renk, tüketici beğenisini, ürünün kabul edilebilirliğini ve tüketicinin tat algisını etkileyen önemli kalite kriterlerinden bir tanesidir (Wadhwani ve McMahon, 2012). Peynirin renk özelliği üzerinde, başta hammadde çiğ sütün rengi olmak üzere, üretim yöntemi, peynirin olgunlaşma durumu, ambalajlama tekniği gibi birçok faktörün etkili olduğu bilinmektedir (Juric vd, 2003).

Çizelge 2. Çökelek peynirlerinin renk değerleri.

Table 2. Color values of çökelek cheeses
Özellikler
Properties
Depolama (Gün)
Storage (Day)
YÇ
$K C$

\begin{tabular}{cccc}
\hline$L^{*}$ & 1 & $70.69 \pm 0.02$ & $70.47 \pm 0.02$ \\
& 14 & $69.87 \pm 0.18$ & $70.02 \pm 0.35$ \\
& 28 & $70.36 \pm 0.36$ & $69.70 \pm 0.54$ \\
\hline$a^{*}$ & 1 & $-0.52 \pm 0.13$ & $-0.55 \pm 0.00$ \\
& 14 & $-0.66 \pm 0.28$ & $-0.52 \pm 0.11$ \\
\hline \multirow{3}{*}{$b^{*}$} & 28 & $-0.62 \pm 0.04$ & $-0.47 \pm 0.09$ \\
\hline & 1 & $6.88 \pm 0.01$ & $7.08 \pm 0.16$ \\
& 28 & $7.26 \pm 0.25$ & $7.12 \pm 0.14$ \\
\hline
\end{tabular}

YÇ: Yoğurt kullanılarak üretilen Çökelek peyniri (kontrol), KÇ: Kefir kullanılarak üretilen Çökelek

YC: Cökelek, cheese produced from yogurt (control), KC: Cökelek, cheese produced from kefir 
Çökelek peyniri taze olarak tüketildiğinde beyazlık özelliği ile bilinen bir peynir çeşididir (Kalender ve Güzeler, 2013). Bu durum geleneksel olarak üretiminde hammadde yoğurdun yayıklama işlemiyle yağının ayrılmasıyla elde edilen yayık ayranının kullanımına bağlıdır. Çökelek peyniri örnekleri renk özellikleri açısından karşılaştırıldıklarında elde edilen değerlerin benzer olduğu saptanmıstır $\left(\begin{array}{ll}P & >0.05\end{array}\right)$. Ayrıca, depolamanın çökelek peynirlerinin renk özelliklerini istatistiksel açıdan önemli düzeyde etkilemediği $(P>0.05)$ belirlenmiştir. $L^{*}$ değeri parlaklığ1 simgeleyen bir renk parametresi olarak; $0=$ karanlık, $100=$ parlaklık olmak üzere bir değişim aralığına sahiptir. $a^{*}$ değerinin (-) olması yeşil rengin, (+) olması ise kırmızı rengin göstergesi iken, $b^{*}$ değerinin (-) olması mavi rengin, $(+)$ olması ise sarı rengin göstergesi olarak kabul edilmektedir (Pathare vd., 2013). Yoğurt ve kefirden üretilen çökelek peynirlerinin $L^{*}$ değerlerinin 69.70-70.69 arasında değiştiği Çizelge 2'den görülmektedir. Şanlıdere Aloğlu vd. (2012) çalışmalarında farklı üreticilerden toplanan 21 adet Minci peynirinde $L^{*}, a^{*}$ ve $b^{*}$ değerlerini sirasiyla, $83.99-97.40,-1.84-0.73$ ve $8.02-18.81$ olarak belirlemişlerdir. Minci peyniri örneklerinin, hammadde ve üretim yöntemi yönünden olas1 farklılıklar taşıması nedeniyle renk değerleri bakımından geniş bir değişim gösterdiği belirtilmiştir. Mevcut çalışma örneklerinde ise $L^{*}$, $a^{*}$ ve $b^{*}$ değerlerinin değişim aralı̆̆ daha dardır. Yoğurt ve kefir çökelek peynirlerinin $a^{*}$ değeri bakımından yeşil ve $b^{*}$ değeri bakımından ise sarı renk bölgesinde yer aldığ1 söylenebilir. Benzer sonuçları, Şanlıdere Aloğlu vd. (2012) çökelek örneklerinde tespit etmiş olmasına rağmen Celem vd., (2018), çökelek örneklerinde $a^{*}$ değerleri bakımından farklı sonuçlar elde etmiştir.

Aynı hammadde kullanılarak üretilen yoğurt ve kefirden üretilen çökelek peynirlerinde, kullanılan starter kültürler ve inkübasyon koşulları dışında aynı prosedürün takip edilmiş olması genel bileşim özellikleri ve renk değerleri bakımından benzer sonuçların elde edilmesinin nedenidir. $\mathrm{Bu}$ durumu ortaya koymak üzere örneklerin renk değerleri bakımından farkını ortaya koyan bir renk indisi olan $\Delta E$ değeri depolama günlerinde hesaplanmıstır. Hesaplama yapılırken, çökelek peyniri üretiminde kefir kullanımının etkisini gözlemlemek amacıyla yoğurttan üretilen çökelek peyniri kontrol örneği olarak kabul edilmiştir. $\Delta E$ değerinin yüksekliği örneklerin kontrol örneğinden farkllı̆ğının derecesini göstermektedir (Chudy vd., 2019). $\Delta E<1.5$ iken renk açısından küçük farklllığın olduğu ifade edilmektedir (Pathare vd., 2013). Kefir çökeleği örneği için depolamanin 1., 14. ve 28. günlerinde hesaplanan $\Delta E$ değerleri sırasıyla, $0.24,0.25$ ve 0.40 'dır. $\mathrm{Bu}$ değerler $\Delta E<1.5$ olduğu için kefirden üretilen çökelek peynirinin renk özelliği açısından yoğurttan üretilen çökelek peyniri ile kıyaslandığında çok küçük bir farklilığın olduğu söylenebilir.

\section{Duyusal değerlendirme}

Çökelek peynirlerinin koku, görünüş, tat, yap1 ve genel kabuledilebilirlik gibi duyusal özellikleri panelistler tarafindan 10 tam puan üzerinden değerlendirilmiştir. Depolama günlerinde elde edilen sonuçların ortalama değerleri Şekil 2'de verilmiştir. Değerlendirmenin ilk aşamasında panelistler tarafindan örneklerin tat ve koku özellikleri bakımından farklı olduğu ifade edilmiştir. Ancak görünüş ve yap1 özellikleri yönünden ise örnekler arasında fark olmadığ1 belirtilmiştir. Bu durum aynı hammadde çiğ süt kullanılarak üretilen yoğurt ve kefirin benzer bileşime sahip olmaları ve aynı prosedür ile üretilen çökelek peynirlerinin benzer nem içerikleri ile ilişkilendirilmiştir.

Duyusal değerlendirmenin 2. aşamasında tat ve koku yönünden farklılığın derecesi puanlama testi ile değerlendirilmiştir. Koku yönünden değerlendirildiğinde depolamanın 1. günde örnekler arasında fark çok büyük olmamakla beraber yoğurttan elde edilen çökeleğin daha yüksek puan aldığı, 14. ve 28. günlerde ise kefirden üretilen çökeleğin daha yüksek puan aldığ1 belirlenmiştir (Şekil 2). Tat yönünden ise yine örnekler arasında önemli bir fark olmamakla birlikte tüm depolama günlerinde kefirden üretilen çökeleğin daha yüksek puan aldığ1 görülmektedir. $\mathrm{Bu}$ duruma kefir ürününe has tat/aromadan sorumlu olan maya populasyonunun etkisinin olabileceği düşünülmektedir. Kefir ürününün tat/aromasindan mayaların 
ürettiği alkol ve karbondioksitin sorumlu olduğu ve kefir kültürünün peynirde tat/aroma yönünden katk1 sağladığ1 bildirilmiştir (Nielsen vd., 2014; Bengoa vd., 2018). Genel kabul edilebilirlik özelliği yönünden depolama günleri ortalaması dikkate alındığında, kefirden üretilen çökelek peynirinin daha fazla beğenildiği belirlenmiştir (Şekil 2).
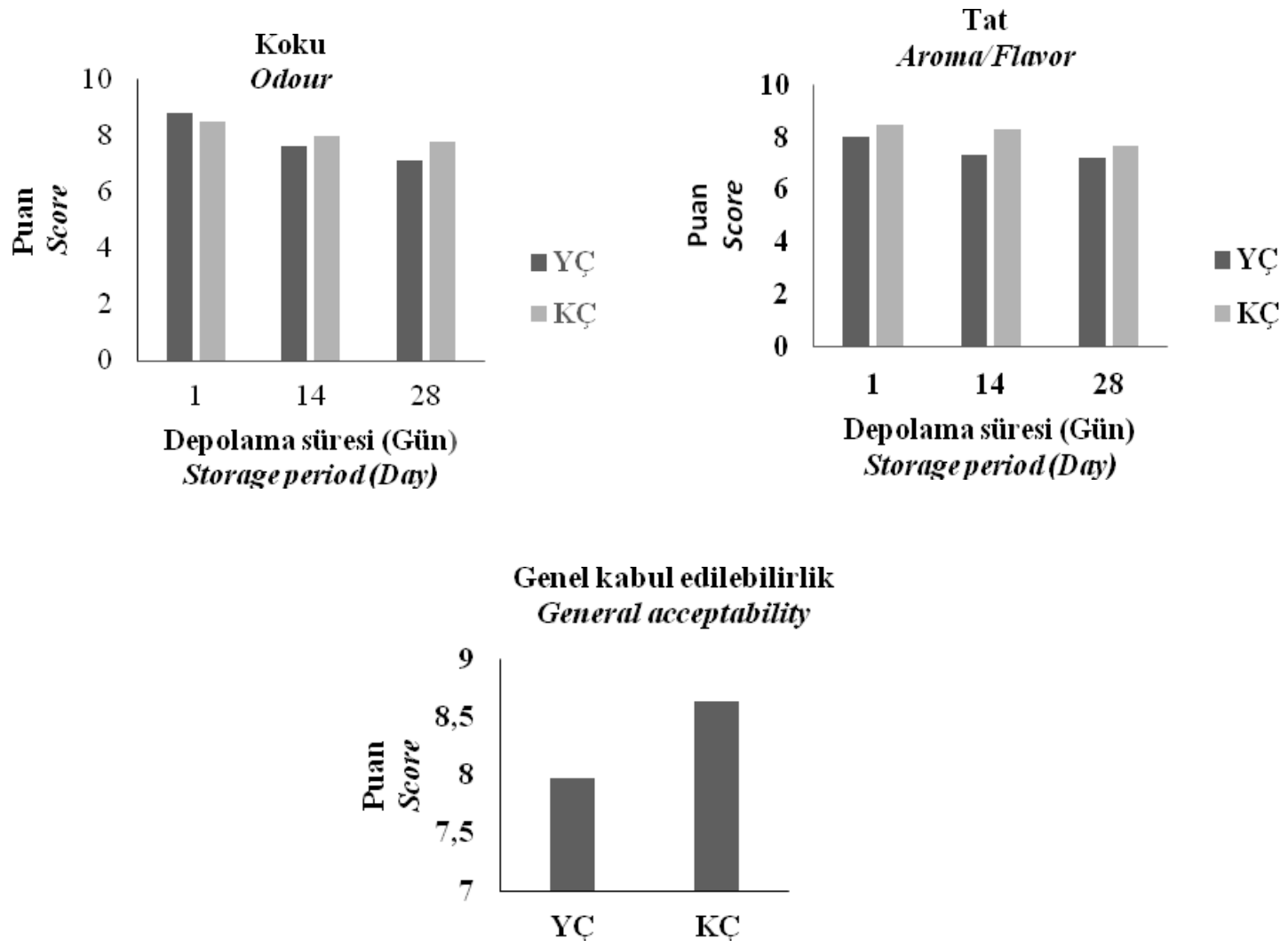

Şekil 2. Çökelek peynirlerinin duyusal değerlendirme sonuçları

Figure 2. Sensory evaluation results of Cökelek cheeses

\section{Mikrobiyolojik sayım sonuçları}

Yoğurt ve kefir kullanılarak üretilen çökelek peynirlerinin TAMB sonuçları Çizelge 3'de verilmiştir. Çökelek peyniri örneklerinin depolamanın 1., 14. ve 28. günlerinde belirlenen TAMB düzeyleri arasındaki farkllık istatistiksel açıdan önemli bulunmuştur $(P<0.05)$. Bununla birlikte, örneklerin TAMB sayıları üzerinde depolama günlerinin etkisi değerlendirildiğinde meydana gelen değişimin istatistiksel açıdan önemli olmadığı belirlenmiştir $(P>0.05)$. TAMB sayıs1, ürünlerde hijyenik yetersizliğin bir göstergesi olarak kabul edilir. Çökelek peyniri gibi 1sıl işlem etkisiyle piht1 elde edilen peynir türlerinde TAMB sayısındaki muhtemel yükseklik, çiğ sütün mikrobiyel kalitesi, 1sıya dayanıklı mikroroganizmaların varlığ ve 1 sil işlem sonrası uygulamalara (torbadan süzme, bask1 uygulamas1, paketleme vb.) bağlı olabilmektedir (Temiz vd., 2009). Yoğurttan ve kefirden üretilen çökelek peynirlerinde TAMB düzeylerinin depolama süresince sirasiyla, 3.31-3.58 log kob/g ve 2.71- 
$2.96 \log \mathrm{kob} / \mathrm{g}$ aralığında değiştiği belirlenmiştir. Dimitrellou vd., (2015), tarafindan Feta tipi peynirlerde kefir kültürü kullanımının bozulma etmeni olan ve patojen mikroorganizma faaliyetini baskılayıc1 etki yarattığı bildirilmiştir. Bengoa vd., (2018) çalışmalarında kefir mikroflorasında bulunan laktik asit bakterilerinin ürettikleri laktik asit, asetik asit ve antimikrobiyel bileşenlerin ürünlerde koruyucu etki yarattığını belirlemişlerdir. Nielsen vd., (2014) tarafından, peynir üretiminde kefir kültürü kullanımının tat/aroma yönünden ümit vadedici olduğu ve mikrofloranın antimikrobiyel etkisi nedeniyle peynirin raf ömrünü uzatıcı etki yarattığ1 bildirilmiştir. Benzer şekilde, çalışmada kefirden üretilen çökelek peyniri örneklerinde daha düşük TAMB değerleri elde edilmiştir (Çizelge 3). Depolamanın 1. gününde TAMB değerlerinin 14. gün değerlerine göre daha yüksek olduğu görülmektedir. Fox vd. (1993) tarafindan TAMB sayısının depolamanın 7. gününe kadar artış gösterip, 7. günde maksimuma ulaşttğ1 ve ilerleyen günlerde azaldığı belirtilmiştir. Bu durum her iki deneme örneğinde de depolamanın 14. gününe kadar gözlenmiştir. Ancak depolamanın 28. gününde her 2 örnekte de TAMB değerlerinde artış gözlenmiş, değerler 1. gün değerlerine ulaşmıştır (Çizelge 3).

Çizelge 3. Çökelek peynirlerinin mikrobiyolojik sayım sonuçları (log kob/g) Table 3. Microbiological counts of çökelek cheeses $(\log c f u / g)$

\begin{tabular}{lccc}
\hline & $\begin{array}{c}\text { Depolama (Gün) } \\
\text { Storage (Day) }\end{array}$ & YÇ & KÇ \\
\hline Toplam aerobik & 1 & $3.58 \pm 0.06^{\mathrm{a}}$ & $2.96 \pm 0.06^{\mathrm{b}}$ \\
mezofilik bakteri & 14 & $3.31 \pm 0.22^{\mathrm{a}}$ & $2.71 \pm 0.01^{\mathrm{b}}$ \\
Total aerobic mesophilic & 28 & $3.51 \pm 0.08^{\mathrm{a}}$ & $2.95 \pm 0.07 \mathrm{~b}$ \\
bacteria & &
\end{tabular}

YÇ: Yoğurt kullanılarak üretilen Çökelek peyniri (kontrol), KÇ: Kefir kullanılarak üretilen Çökelek peyniri Aynı satırda farklı harflerle gösterilen örnek ortalamaları arasındaki farklılı önemli bulunmuştur $(P<0.05)$ YC: Cökelek cheese produced from yogurt (control), KC: Cökelek cheese produced from kefir

Difference between sample averages indicated by different letters in the same line was found significant $(P<0.05)$

Çalışmadan elde edilen sonuçlara göre; tüketicinin son dönemde sağlığ1 iyileştirmeye katk1 sağlayan g1dalara eğilimi nedeniyle, kefirden üretilen çökelek peynirinin endüstriyel üretim potansiyeline sahip bir peynir çeşidi olabileceği düşünülmektedir.

\section{KAYNAKLAR}

Altug-Onogur, T., \& Elmaci, Y. (2015). Farkllitk Testleri. İçinde: Gıdalarda Duyusal Değerlendirme, Sidas Medya Ltd. Şti, Izmir, Türkiye, s. 39-61.

Bengoa, A.A., Iraporda, C., Garrote, G.L., Abraham, A.G. (2018). Kefir micro-organism: Their role of grain assembly and health properties of fermented milk. I Appl Microbiol, 126, 686700, doi: 10.1111/jam.14107.
Celem, E., Çelik, Ö.F., Tarakçı, Z. (2018). The effects of ripening on some physicochemical and micribiological chracteristics of Çökelek cheeses: A market survey of fresh and skin-ripened Çökelek. J Cent Euro Agric, 19(2), 335348, doi:10.5513/JCEA01/19.2.2155.

Chudy, S., Makowska, A., Tek, M.P., Bartkowiak, M.K.N. (2019). Application of microwave vacuum drying for snack production: Characteristics of pure cheese puffs. Int J Dairy Technol, 72, 82-88, doi: 10.1111/14710307.12562.

Çardak, A.D. (2012). Mikrobial and chemical quality of Çökelek cheese, Lor cheese and Torba (strained) yoghurt. Afr J Micro Res, 6(45), 72787284, doi: 10.5897/AJMR12.1676. 
Dertli, E., Çon, A.H. (2017). Microbial diversity of traditional kefir grains and their role on kefir aroma. LWT - Food Sci Technol, 85: 151-157, doi: 10.1016/j.lwt.2017.07.017.

Dimitrellou, D., Kandylis, P., Kourkoutas, Y., Koutinas, A.A., Kanellaki, M. (2015). Cheese production using kefir culture entrapped in milk proteins. Appl Biochem Biotechnol, 176, 213-230, doi: 10.1007/s12010-015-1568-4.

Ergene, G., Arslan, S. (2019). Chemical and sensory chracteristics dried Çökelek cheeses at different temperatures. J Food Process Preserv, 43(6), 1-8, doi: 10.1111/jfpp.13985.

Esmek, E.M., Güzeler, N. ( 2015). Kefirve Kefir Kullanılarak Yapılan Bazı Ürünler. Harran tarm ve Gida Bilimleri Dergisi, 19, 250-258.

Fox, P.F. (1993). Cheese: An Overview. In: Cheese:Chemistry, Physics and Microbiology, Fox, P.F. (chief ed.), Chapman and Hall, London UK, pp. 1-36.

Fox, P.F., McSweeney, P.L.H., Wallace, J. (1993). Biochemistry of cheese ripening. In: Cheese:Chemistry, Physics and Microbiology, Fox, P.F. (chief ed.), Chapman and Hall, London UK, pp. 389-438.

Fox, P. F., Guinee, T. P., Cogan, T. M., \& McSweeney, P. L. H. (2017). Fundamentals of cheese science (2nd ed.). New York, NY, USA: Springer. Chapt. 11.

Güzel Seydim, Z., Kök Taş, T., Greene, K., Seydim, A.C. (2011). Review: Functional properties of Kefir. Crit Rev Food Sci Nutr, 51, 261268, doi: 10.1080/10408390903579029.

Halkman, A. K. (2005). Mikroorganizma analizi. Merck Gida Mikrobiyolojisi Uygulamalar, Halkman, A.K. (Ed.), Başak Matbaacılık ve Tanıtım Hizmetleri Ltd. Şti., Ankara, Türkiye, s. 135-136.

Hooi, R., Barbano D.M., Bradley R.L., Budde D., Bulthaus M., Chettiar M. (2004). Chemical and physical methods. In: Standard Methods for the Examination of Dairy Products, Wehr, H.M., Frank, J.F. Washington (chif ed.), DC: American Public Health Association, pp. 363-532.
IDF (1993). "Milk determination of nitrogen content", Standard No: 20B, International Dairy Federation, Brussels, Belgium.

Irkin, R. (2011). Shelf life of unsalted and light "Lor" whey cheese stored under various packaging conditions: Microbiological and sensory attributes. J Food Process Preserv, 35, 163178, doi: 10.1111/j.1745-4549.2009.00469.x.

Juric, M., Bertelsen, G., Mortensen, G., \& Petersen, M.A. (2003). Light-induced colour and aroma changes in sliced, modified atmosphere packaged semi-hard cheeses. Int Dairy J, 13, 239249, doi: 10.1016/S0958-6946(02)00156-5.

Kakisu, E., Irigoyen, A., Torre, P., De Antoni, G.I., G. Abraham, A. (2011). Physicochemical, microbiological and sensory profiles of fermented milk containing probiotic strains isolated from kefir. J Dairy Res, 78: 456-463, doi: 10.1017/S0022029911000653.

Kalender, M., Güzeler, N. (2013). Anamur Yöresi Keş Çeşitleri ve Baz1 Kimyasal Özellikleri. Cukurova Üniversitesi Ziraat Fakë̈ltesi Dergisi, 28 (2), 1-10.

Karabulut, I., Hayaloğlu, A.A., Yıldırım, H. (2007). Thin-layer drying chracteristics of kurut, a Turkisk dried dairy by-product. Int J Food Sci Technol, 42, 1080-1086, do: 10.1111/j.13652621.2006.01351.x.

Kavaz, A., Arslaner, A., Bakırc1, İ. (2012). Comparasion of quality characteristics of Çökelek and Lor cheeses. Afr J Biotechnol, 11(26):68716877, doi: 10.5897/AJB11.4230.

Nielsen, B., Candan Gürkan, G., Ünlü, G. (2014). Kefir: A Multifaceted fermented dairy product. Probiotics Antimicro Prot, 6, 123-135, doi: 10.1007/s12602-014-9168-0.

Pathare, P.B., Opara, U.L., \& Al-Julanda Al-Said, F. (2013). Colour measurement and analysis in fresh and processed foods: A review. Food Bioprocess Technology, 6, 36-60, doi: 10.1007/s11947-012-0867-9.

Ribeiro Melo, D.R., Silva, P.H.T. da, Rigoto, R.P., Sottoriva, H.M., Cintra, F.F., Trento, J.P., Castro, A.L. de,Alves, G. (2018). Quark cheese produced with kefir and agave inulin. Arquivos de Ciências 
Veteriárias e Zoologia UNIPAR, Umuarama, 21(3), 87-92, doi: 10.25110/arqvet.v21i3.2018.7337.

Simova, E., Bershkova, D., Angelov, A., Hrisyova, T., Frengova, G., Spasov, Z. (2002). Lactic acid bacteria and yeasts in kefir grains and kefir made from them. J Ind Microbiol Biotechnol, 28. 1-6, doi: 10.1038/sj/jim/7000186.

Şanlıdere Aloğlu, H., Turhan, İ, Öner, Z. (2012). Minci (Minzi) peynirin özelliklerinin belirlenmesi. Grda 37(6): 349-354.

Temiz, H., Aykut, U., \& Hursit, A. (2009). Shelf life of Turkish whey cheese (Lor) under modified atmosphere packaging. Int J Dairy Technol, 62, 378e386, doi: 10.1111/j.1471-0307.2009.00511.x.

Ürkek, B., Erkaya, T., Şengül, M. (2011). Kefir: Bileşimi, üretimi, probiyotik ve terapötik özellikleri. Akademik Grda, 9(5), 60-66.
Wadhwani, R., McMahon, D.J. (2012).Color of low-fat cheese influences flavor perception and consumer liking. J Dairy Sci, 95: 2336-2346, doi: 10.3168/jds.2011-5142.

Weschenfelder, S., Pinto Paim, M., Gerhardt, C., Chaves Carvalho, H.H., Maria, Wiest, M. (2018). Antibacterial activity of different formulations of cheese and whey produced with kefir grains. Rev Ciênc Agron, 49(3), 443-449, doi: 10.5935/18066690.20180050 .

Yıldız-Akgül, F., Yetişemiyen, A., Şenel, E., Yildırm, Z. (2018). Microbiological, physicochemical, and sensory characteristics of kefir produced by secondary fermentation. Mbjearstvo, 68(3), 201-213, doi: 10.15567/ mljekarstvo.2018.0305. 